\title{
Potensi Geodiversity di Sekitar Kawasan Anak Krakatau- Way Kambas, Provinsi Lampung, Sebagai Kandidat Geopark Indonesia
}

Received $07^{\text {th }}$ September 2020 Accepted $23^{\text {rd }}$ Febuary 2021 Published $11^{\text {th }}$ March 2021

Open Access

DOI:10.35472/jsat.v5i1.318

\author{
Happy Christin Natalia *a,b, Danni Gathot Harbowo ${ }^{a, b}$, Rinaldi Ikhram a,b \\ a Program Studi Teknik Geologi, Institut Teknologi Sumatera \\ ${ }^{b}$ Pusat Riset dan Inovasi Wisata Geopark Global dan Wisata Langit, Institut Teknologi Sumatera \\ *Corresponding E-mail: happy.natalia@gl.itera.ac.id
}

Abstract: Krakatau Volcanis Complex and Way Kambas National Park's global significance is potential area to be developed as part of a world heritage, particularly as UNESCO Global Geopark. Both of these objects are located in the Lampung Province, Indonesia. Soon, it is necessary to identify and to make an inventory of key sites that could become the area's theme. The study of geodiversity and scientific valuation were carried out which referred to the Technical Guidelines for the Assessment of Indonesia Geological Heritage Resources, 2019. Based on these studies and assessments, 14 key sites are representing Geopark Krakatau-Way Kambas themes. These sites are closely related to the evolution of tectonic activity in the Southern Sumatera and the dynamics of magmatism and paleovolcanism that have occurred since the Mesozoic which has signification in human history as world heritage.

Keywords: geodiversity, Krakatau, Lampung, UNESCO Global Geopark, Way Kambas.

Abstrak: Signifikansi global Gunungapi Anak Krakatau dan Taman Nasional Way Kambas merupakan hal yang potensial untuk dikembangkan sebagai bagian dari kawasan warisan dunia, khususnya UNESCO Global Geopark. Kedua objek ini berada di wilayah admnistrasi Provinsi Lampung. Bersamaan dengan itu perlu dilakukan identifikasi dan inventaris situs-situs kunci yang dapat menjadi tema kawasan tersebut, meliputi Kabupaten Lampung Selatan, Kota Bandar Lampung, Kabupaten Pesawaran, dan Kabupaten Lampung Timur. Pada situs-situs potensial yang ditemukan, dilakukan kajian geodiversity dan scientific value yang mengacu pada Petunjuk Teknis Asesmen Sumberdaya Warisan Geologi, terbitan Pusat Survei Geologi tahun 2019. Berdasarkan kajian dan penilaian tersebut, didapatkan 14 situs kunci yang dapat menjadi tema besar kandidat kawasan UNESCO Global Geopark Krakatau-Way Kambas. Situs-situs tersebut sangat erat kaitannya dengan evolusi aktivitas tektonik di selatan Pulau Sumatera serta dinamika magmatisme dan paleo-volcanic yang berlangsung sejak Mesozoikum hingga saat ini, dan memiliki signifikasi pada sejarah kehidupan manusia modern sebagai warisan dunia.

Kata Kunci : Keragaman Geologi, Krakaktau, Lampung, UNESCO Global Geopark, Way Kambas.

\section{Pendahuluan}

Peninjauan keragaman geologi (geodiversity) di suatu kawasan menjadi penting untuk ditinjau sebagai kandidat sebuah kawasan geopark [1],[2]. Geodiversity dimaknai sebagai suatu kondisi hadirnya variasi material penyusun bumi, bentuk, dan proses yang menyusun dan membentuk bumi, baik secara menyeluruh ataupun fokus hanya pada spesifik area tertentu [3],[4]. Berdasarkan Peraturan Presiden Republik Indonesia No. 9 tahun 2019, geodiversity didefinisikan sebagai gambaran keunikan komponen geologi seperti mineral, batuan, fosil, struktur geologi, dan bentang alam yang menjadi kekayaan hakiki suatu daerah serta keberadaan, kekayaan penyebaran, dan keadaannya yang dapat mewakili proses evolusi geologi daerah tersebut, sebagai bagian yang merepresentasikan warisan geologi (geoheritage) [5].
Meninjau bentang alam di wilayah administrasi Provinsi Lampung, wilayah ini setidaknya dapat dibagi menjadi tiga fisiografi, yaitu Lajur Jambi-Palembang, Lajur Bukit Barisan, dan Lajur Bengkulu, serta dengan komposisi morfologi secara umum, yaitu merupakan dataran rendah, perbukitan bergelombang, pegunungan, dan kerucut gunungapi [6]. Tatanan tektonik yang dibentuk bersamaan dengan penujaman Lempeng Indo-Australia pada Lempeng Eurasia, yang telah menujam membentuk Busur Sunda (Sunda-Arc) di lepas pantai barat Sumatera. Hal ini bersamaan dengan perkembangan utama Sesar Selat Sunda dan Sesar Sumatera [7],[8]. Proses ini berlangsung sejak Mesozoikum hingga saat ini. Selain itu komposisi batuan yang menyusun wilayah ini meliputi batuan alas (bedrock) malihan Pra-Mesozoikum, batuan beku Mesozoikum-Kenozoikum, serta runtuhan batuan sedimen serta gunungapi berumur Tersier sampai 
dengan Kuarter [9]. Dalam hamparan bentang alam tersebut, saat ini terdapat Gunungapi Anak Krakatau dan Kawasan Taman Nasional Waykambas yang memiliki potensi sebagai warisan dunia (world heritage).

Gunungapi Anak Krakatau dan Kawasan Taman Nasional Way Kambas merupakan area yang memiliki signifikansi tingkat global [10],[11],[12]. Perkembangan dan aktivitas erupsi pada Kompleks Gunungapi Krakatau diakui memiliki dampak global pada rekam sejarah manusia, terutama laporan dari aktivitas serta letusan Gunung Krakatau pada tanggal 26-27 Agustus 1883 [10],[13]. Letusan tersebut selain menyebabkan tsunami yang sangat merusak, dampak letusan yang dihasilkan turut tercatat telah mampu berdampak pada iklim dunia [11], [12], [14]. Selain itu, kawasan Taman Nasional Way Kambas merupakan kawasan di dunia yang masih menyimpan lima mamalia besar IndoPasific yang kini hampir punah, mengacu pada International Union for Conservation of Nature (IUCN), yaitu gajah sumatera (Elephant maximus Sumateranus), harimau sumatera (Panthera tigris Sumaterae), badak sumatera (Dicerorhinus sumatrensis), tapir sumatera (Tapirus indicus), dan beruang madu sumatera (Helarctos malayanus). Sejarah geologi dan rangkaian evolusi biodiversitas pada kawasan ini sejalan dengan penyusun nilai ragam geologi yang ditemukan [3],[16]. Sejak tahun 2016, kawasan Taman Nasional Way Kambas telah ditetapkan sebagai ASEAN Heritage Park. Mengacu pada bentang lintasan kedua situs terkemuka tersebut, yaitu Gunungapi Anak Krakatau dan Taman Nasional Waykambas, dalam publikasi ini kami menjabarkan hasil eksplorasi lebih lanjut area-area lain yang representatif untuk menjelaskan keragaman geologi berdasarkan dua global sigificance sites tersebut.

Pulau Sumatera terletak di sepanjang tepi baratdaya Paparan Sunda, pada perpanjangan Lempeng Eurasia hingga daratan Asia Tenggara dan merupakan bagian dari Busur Sunda. Kerak samudera yang mendasari Samudera Hindia dan sebagian Lempeng India-Australia telah miring di sepanjang Palung Sunda di lepas pantai barat Sumatera [17]. Garis subduksi miring ini termasuk dalam sistem Palung Busur Sunda [18] yang membentang lebih dari 5000 km dari Burma hingga Indonesia bagian timur.

Penunjaman ke bawah Sumatera selama Tersier Bawah hingga Resen telah menyebabkan busur magmatik luas di pegunungan Bukit Barisan. Namun, beberapa unit litologi di seluruh Sumatera yang berhubungan dengan busur, menunjukkan bukti subduksi yang telah berlangsung sejak Perem Akhir [19], atau Perem Awal-Tengah [20], [21], dan/ atau Trias Awal Kapur Akhir [22].
Posisi busur dan palung vulkanik saat ini mungkin telah terjadi sejak Miosen. Gaya tekan akibat subduksi miring telah dilepaskan secara berkala melalui sesar geser yang sejajar dengan tepi lempeng. Hal ini dibuktikan dengan sistem sesar Sumatera yang membentang di sepanjang pulau dan membungkus Busur Bukit Barisan. Di jalur busur vulkanik, dapat ditemukan aktivitas gunung api purba dari zaman Miosen-Pleistosen, hingga yang terbaru, termasuk fenomena yang paling mengerikan yaitu Gunung Krakatau [17].

Krakatau adalah gunung berapi aktif yang terletak di persimpangan Sumatera dan Pulau Jawa. Gunung berapi ini menandai perubahan sistem subduksi dari miring di sepanjang Sumatera menjadi tegak lurus di sepanjang Jawa. Kompleks Gunungapi Krakatau terletak sekitar 141 km dari Palung Jawa di baratdaya gunung berapi, sedangkan zona Benioff berada pada kedalaman sekitar $120 \mathrm{~km}$ di bawah gunung berapi [14].

Litologi penyusun kawasan Kandidat Geopark Krakatau- Way Kambas dapat dilihat pada Gambar 1 [7], [8]. Batuan tertua yang tersingkap di daerah Lampung adalah Kelompok Gunung Kasih yang terdiri atas batuan metamorf sekis amfibol dan amfibolit hijau, menyebar di bagian selatan satuan granodiorit (Biru, kode Pzgs,). Setelahnya, terdapat plutonik yang terdiri atas granodiorit dan diorit yang merupakan batuan beku dalam komposisi intermedietsedikit asam dan diperkirakan berumur kapur (> 66 juta tahun yang lalu). Satuan ini menyebar di bagian utara daerah pemetaan (warna ungu, kode Kgdsn). Batuan yang lebih muda berumur Eosen yaitu sumbat basalt, dimensi dan sebarannya tidak terlalu besar dan menerobos batuan jenis lain (warna coklat, kode Tpeb). Berikutnya yang lebih muda adalah Formasi Tarahan, yang terdiri atas asosiasi tuf dengan breksi sisipan rijang, berumur Oligosen, penyebarannya memanjang di bagian barat dari utara ke selatan (warna oranye, kode Tpot). Satuan berikutnya yang lebih muda, Formasi Sabu, terdiri dari breksi konglomeratan dan batupasir berumur Oligosen Akhir; Formasi Surungbatang berupa tuf, breksi tufan, tuf pasiran dan batupasir greywacke berumur Pliosen; dan Formasi Lampung berupa tuf lapilli, batulempung tufan, dan batupasir tufan, berumur Kuarter. Penyebaran Formasi Lampung ini paling luas dari tengah kearah selatan dan timur. Kemudian lava andesit berumur Pliosen dengan karakteristik kekar lembaran. Satuan termuda berumur Resen berupa endapan alluvial [7], [8].

Penelitian ini bertujuan untuk mengidentifikasi dan menginventaris potensi lokasi khusus yang dapat merepresentasikan geodiversity dan nilai ilmiah di wilayah yang dikaji. Sebagai batasan kajian ini meliput 
wilayah administrasi Kabupaten Lampung Selatan, Kota Bandar Lampung, Kabupaten Pesawaran, dan Kabupaten Lampung Timur. Hasil identifikasi dan inventaris ini akan memiliki makna besar untuk usulan kandidat kawasan Geopark Krakatoa-Way Kambas, sebagai bagian dari UNESCO Global Geopark.
Geologi dan Petunjuk Teknis Penetapan Warisan Geologi dari Badan Geologi Indonesia [24].

Data litologi dan umur batuan/bentang alam setiap titik geodiversity diselaraskan dengan Peta Geologi Lembar Tanjung Karang [7] dan analisis geomorfologi didasarkan pada pengolahan citra Digital Elevation Model Shuttle

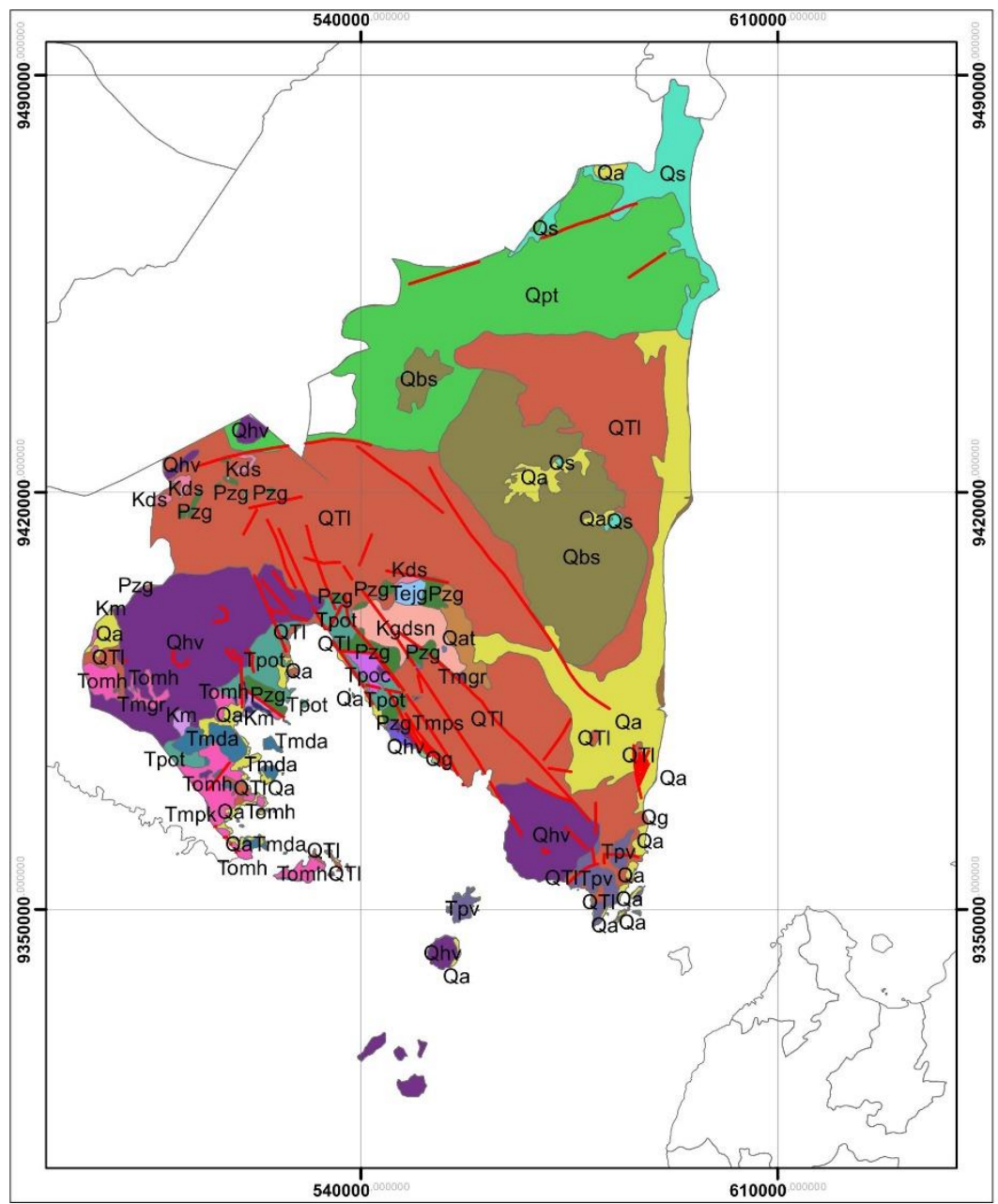

\section{PETA GEOLOGI KAWASAN KRAKATAU - WAY KAMBAS}

Kota Bandar Lampung, Kabupaten Lampung Selatan, Kabupaten Lampung Timur, Kabupaten Pesawaran

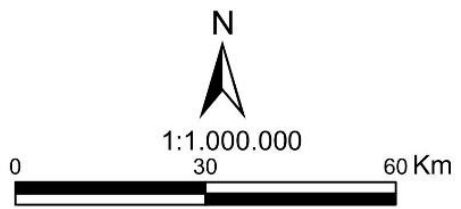

Legenda

Kelurusan $\longrightarrow$ Batas wilayah kabupaten

\section{Keterangan}

\begin{tabular}{|c|c|c|c|}
\hline Qa & Alluvium & Tpot & Formasi Tarahan \\
\hline Tpv & Andesit & Qpt & Formasi Terbanggi \\
\hline Qbs & Basal Sukadana & Tmgr & Granit \\
\hline $\mathrm{Qg}$ & Batugamping Koral & Tejg & Granit Jatibaru \\
\hline Tmda & Dasite Piabung & $\mathrm{Tm}$ & Granit Seblat \\
\hline Kds & Diorit Sekampung Terpoliasi & Kgdb & Granodiorit Branti \\
\hline Qs & Endapan Danau & Kgdsn & Granodiorit Sulan \\
\hline Tpoc & Formasi Campang & Qhv & Gunungapi Muda \\
\hline Tomh & Formasi Hulusimpang & Pzg & Kompleks Gunung Kasih \\
\hline Tmpk & Formasi Kantur & Tpeb & Sumbat basal \\
\hline Qtl & Formasi Lampung & Qat & Undak Alluvium \\
\hline $\mathrm{Km}$ & Formasi Menanga & & \\
\hline Tpos & Formasi Sabu & & \\
\hline Tmps & Formasi Surungbatang & & \\
\hline
\end{tabular}

Gambar 1 Peta geologi di sekitar Kawasan Krakatau Waykambas (modifikasi Mangga dkk, 1993 dan Gafoer dkk,1993).

\section{Metode Penelitian}

Data-data geodiveristy diperoleh dari sumber referensi, artikel, paper ilmiah, dan survei lapangan. Luas wilayah penelitian meliputi satu kota dan tiga kabupaten, yaitu Kota Bandar Lampung, Kabupaten Lampung Selatan, Kabupaten Lampung Timur dan Kabupaten Pesawaran. Pengategorian dan penilaian geodiversity dilakukan dengan mengacu pada Peraturan Menteri ESDM Indonesia [23] Tentang Pedoman Penetapan Warisan
Radar Topography Mission (DEM SRTM). Terdapat 44 titik lokasi geodiversity yang dianalisis dalam penelitian ini. Komponen geodiversity dibagi pada 5 aspek yakni mineral, batuan, fosil, struktur geologi, dan bentang alam, dengan nilai pembobotan 0-4 (Tabel 1) [24]. Pembobotan lainnya dalam memberi penilaian aspek ilmiah meliputi aspek lokasi yang memiliki kerangka geologi, lokasi kunci penelitian, pemahaman keilmuan, kondisi lokasi, keanekaragaman geologi, pesebaran 
geosite dalam satu wilayah, dan hambatan penggunaan lokasi dengan bobot 0-100 (Tabel 2) [24].

Komponen-komponen penilaian disajikan dalam bentuk tabel dengan rincian pada Tabel 1-2 berikut ini.

Tabel 1 Pengelompokkan jenis geodiversiti [24].

\begin{tabular}{|l|c|c|c|c|c|c|c|}
\hline \multirow{2}{*}{ NO } & \multirow{2}{*}{ GEOSITE } & Mineral & Batuan & Fosil & $\begin{array}{c}\text { Struktur/ } \\
\text { tektonik/ } \\
\text { proses }\end{array}$ & $\begin{array}{c}\text { Bentang } \\
\text { alam }\end{array}$ & Pembobotan \\
\cline { 3 - 8 } & 25 & 30 & 5 & 25 & 15 & 100 \\
\hline & & & & & & & \\
\hline
\end{tabular}

Tabel 2 Pembobotan geosite/geodiversiti untuk aspek ilmiah, edukasi, pariwisata dan resiko degradasi [24].

\begin{tabular}{|c|c|c|c|c|c|c|c|c|c|c|}
\hline NO & $\begin{array}{l}G \\
E \\
O \\
S \\
I\end{array}$ & $\begin{array}{l}\text { K } \\
\text { A } \\
\text { T } \\
\text { E } \\
\text { G } \\
\text { O }\end{array}$ & (1) & (2) & (3) & (4) & (5) & (6) & (7) & (8) \\
\hline & $\mathrm{E}$ & $\begin{array}{l}\mathbf{R} \\
\mathbf{I}\end{array}$ & 30 & 20 & 5 & 15 & 5 & 15 & 10 & 100 \\
\hline & & & & & & & & & & \\
\hline
\end{tabular}

Keterangan:

1. Lokasi yang memiliki kerangka geologi

2. Lokasi kunci penelitian

3. Pemahaman keilmuan

4. Kondisi lokasi/situs geologi

5. Keanekaragaman geologi

6. Persebaran geosite dalam satu wilayah

7. Hambatan penggunaan lokasi

8. pembobotan

\section{Hasil dan Pembahasan}

Dari 44 lokasi geodiversity yang telah diolah dan dianalisis (Gambar 2), terdapat 14 titik yang memiliki nilai geodiversity lebih tinggi dibandingkan daerah lainnya (Gambar 4 dan 5). Keempat belas lokasi ini dinilai dapat memberikan gambaran evolusi tektonik, evolusi magmatisme purba dan resen di kawasan Kandidat Geopark Krakatau-Way Kambas. Penjelasan penilaian lebih rinci dapat dilihat pada Tabel 3, 4, dan 5 dalam Lampiran. Berdasarkan aktivitas tektonik dari tua ke muda, 14 titik lokasi geodiversity tersebut sebagai berikut:

1. Jeram Migmatit Natar (23): Lokasi ini berada di bagian utara daerah penelitian, Kecamatan Natar, Lampung Selatan. Pada poin lokasi yang memiliki kerangka geologi dan lokasi kunci penelitian, lokasi ini memiliki nilai tinggi, karena pembentukan batuan migmatit berkaitan erat dengan evolusi tektonik yang terjadi. Keberadaan migmatit menunjukan kondisi temperatur tinggi yang terjadi pada suatu batuan sehingga menyebabkan terjadinya peleburan sebagian [25]. Batuan ini termasuk pada kelompok batuan Migmatit Judeng yang berumur lebih dari 200 juta tahun dan merupakan batuan paling tua yang tersingkap di area kajian (Gambar 1 dan 2) [25]. Sekali pun memiliki singkapan batuan yang menarik, untuk mencapai lokasi ini cukup sulit karena berada di dasar sungai. Berdasarkan kondisi geologi tersebut, Jeram Migmatit Natar memiliki nilai geodiversity 23,5\% (Gambar 3) dan aspek ilmiah 85\% (Gambar 4).

2. Bukit Malihan Pra-Tersier Panjang (2): Bukit Malihan Pra-Tersier Panjang berada di Kecamatan Panjang, Bandar Lampung. Lokasi geodiversity ini memiliki variasi mineral malihan dengan protolit dari batuan sedimen (kuarsit dengan perselingan sekis-kuarsa serisit) dan protolit dari batuan beku (sekis amfibol hijau dan dioritik-amfibolit) [6]. Bentuk shear-joints dapat ditemukan pada satuan batuan resisten. Hal ini memberikan nilai geodiversity cukup tinggi pada lokasi berikut, yaitu 15,25\% (Gambar 3). Pada area ini dapat ditemukan area pertambangan (umumnya sebagai Pertambangan Bahan Galian C) dan aktivitas industri lain yang terkoneksi dengan Pelabuhan Panjang. Namun, hal ini bukanlah hambatan untuk mencapai lokasi geodiversity. Lokasi ini merupakan bagian dari Komplek Gunungkasih berumur PraTersier (Gambar 1 dan 2, kode Pzg) dan memiliki bukti-bukti publikasi cukup baik [7]. Berdasarkan hal ini, maka nilai ilmiah lokasi geodiversity ini adalah 81,25\% (Gambar 4).

3. Bukit Granit Indah (16): Lokasi ini berada di Kecamatan Jabung, Lampung Timur. Bukit Granit Indah memiliki nilai geodiversity 15,25\% (Gambar 3) karena memiliki morfologi monadock yaitu sebuah pegunungan terisolasi yang tersusun atas batuan yang resisten (tahan terhadap pelapukan) yang dikelilingi oleh dataran [26]. Sekali pun pesebaran geodiversity daerah ini tidak beragam namun bentang alam lokasi ini cukup indah. Kehadiran granit di daerah ini memiliki hubungan erat dengan aktivitas tektonik yang terjadi pada Mesozoikum dan memberi nilai tambah pada penilaian ilmiah daerah ini [6]. Bukit Granit Indah dikelompokan sebagai Granodiorit Sulan dengan umur Mesozoikum (Gambar 1 dan 2, kode Kgdsn) [7]. Namun, penelitian yang berkaitan 


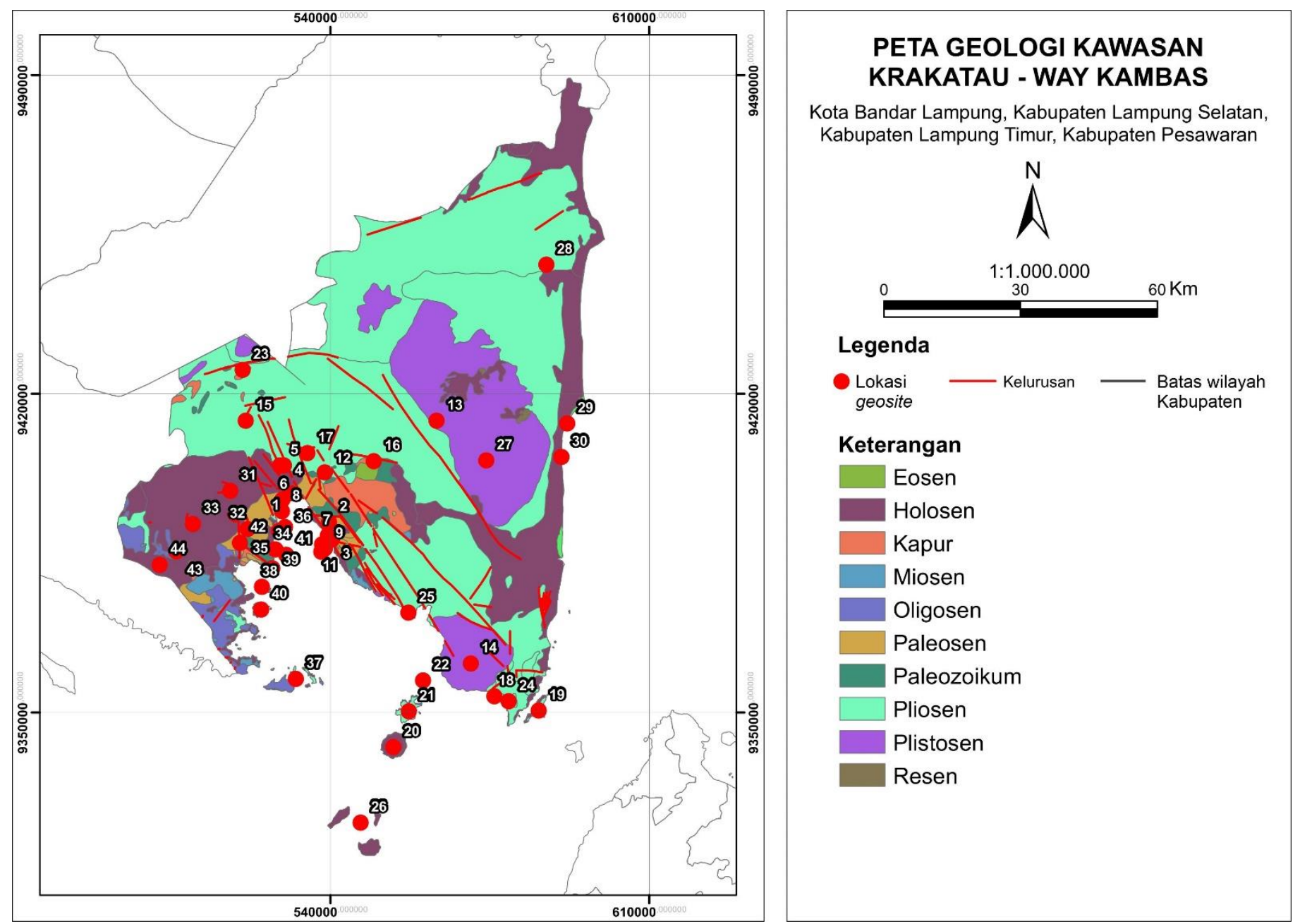

Gambar 2 Peta geologi berdasarkan umur geologi dan titik-titik lokasi geodiversity di sekitar Kawasan Kandidat Geopark Krakatau-Way Kambas (Modifikasi Mangga dkk, 1993 dan Gafoer dkk, 1993).

dengan batu granit di daerah ini cukup sedikit. Oleh sebab itu, aspek ilmiah daerah ini adalah 77,50\% (Gambar 4).

4. Pantai Sari Ringgung (34): Pantai ini merupakan salah satu pantai yang memiliki dermaga untuk menyusuri deretan pulau-pulau yang ada di sekitar pesisir selatan pantai Lampung. Pantai Sari Ringgung berada di Kecamatan Padang Cermin, Kabupaten Pesawaran. Litologi di sekitar pantai cukup beragam, mulai dari perselingan breksi konglomerat-batupasir (Fm. Campang, kode Tpoc) berumur Eosen, serpihbatulempung ( $\mathrm{Fm}$. Menanga, kode $\mathrm{Km}$ ) berumur Kapur dan juga tuf dari Gunung Gebang Tua [6].
Selain itu bentang alam dan morfologi pantai di daerah ini sangat indah. Hal tesebut memberikan nilai geodiversity daerah ini yaitu 18,5\% (Gambar 3). Kehadiran litologi berumur Kapur hingga Eosen menunjukkan bahwa keberadaan daerah ini tidak lepas dari pengaruh evolusi tektonik pada umur tersebut [20]. Namun, sekali pun memiliki nilai geodiversity cukup tinggi, daerah ini memiliki hambatan dalam penggunaannya (Gambar 1 dan 2 ). Hal ini disebabkan karena daerah ini merupakan bagian dari teritorial TNI AL. Penilaian aspek ilmiah lokasi ini adalah 73,75\% (Gambar 4). 
5. Kaldera Purba Gebang (31): Lokasi geodiversity ini berada di Kecamatan Teluk Betung Barat, Bandar Lampung. Bentuk morfologi Kaldera Purba Gebang disusun oleh tuf padu, breksi dengan sisipan rijang yang merupakan bagian dari Formasi Tarahan (Tpot), berumur Eosen dan lava (andesit-basalt), tuf, dan breksi yang merupakan bagian dari Formasi Hulusimpang (Tmoh) berumur Oligosen hingga Miosen Awal (Gambar 1 dan 2) [7]. Lokasi ini berdekatan dengan Pantai Sari Ringgung. Bentuk bentang alam, variasi litologi, dan struktur akibat tektonik di daerah ini cukup baik dan telah memberikan nilai geodiversity 18\% (Gambar 3). Namun, pemahaman keilmuan di daerah ini masih kurang. Kehadiran Formasi Tarahan dan Hulusimpang, serta bentuk morfologi kaldera di daerah ini menunjukkan adanya hubungan antara aktivitas tektonik dan vulkanisme purba pada Kala Tersier, namun lokasi kunci ini masih perlu untuk diteliti lebih lanjut. Lokasi geodiversity ini berada dekat dengan lokasi Teropong Bintang (ITERA Astronomical Observatorium) yang berada di Gunung Betung dan memiliki akses yang mudah untuk dilalui.
Berdasarkan hal tersebut penilaian aspek ilmiah lokasi ini adalah 75\% (Gambar 4).

6. Pantai Batu Lapis (18): Pantai Batu Lapis terletak di pesisir Desa Kunjir, Kecamatan Rajabasa, Lampung Selatan, kira-kira $25 \mathrm{~km}$ dari pusat Kota Kalianda. Berbeda dengan bebatuan karang yang ada dikebanyakan pantai, pantai berbatu sepanjang satu kilometer ini menyerupai punden berundak-undak dan berlapis-lapis. Lapisan ini terbentuk oleh lava, piroklastik, lava tube yang membeku dan membentuk kekar berlembar yang terbentuk pada zaman Pliosen [6] (Gambar 1 dan 2). Selain dari litologi dan struktur batuan yang menarik, lokasi geodiversity ini memiliki bentang alam yang menawan. Hasil penilaian geodiversity ini adalah 18,88\% (Gambar 3). Kehadiran lava dengan struktur kekar berlembar dan juga lava tube memiliki hubungan dengan aktivitas magmatisme berumur Paleosen di bagian pesisir selatan Lampung [7]. Kondisi lokasi geodiversity dan juga pesebaran geodiversity di daerah ini baik. Untuk mencapai lokasi ini dapat dilakukan dari Pantai Kahai, Kalianda, dengan menggunakan perahu. Tinjauan aspek-aspek ilmiah di daerah ini menunjukkan nilai yang cukup baik, yaitu 65\% (Gambar 4 ).

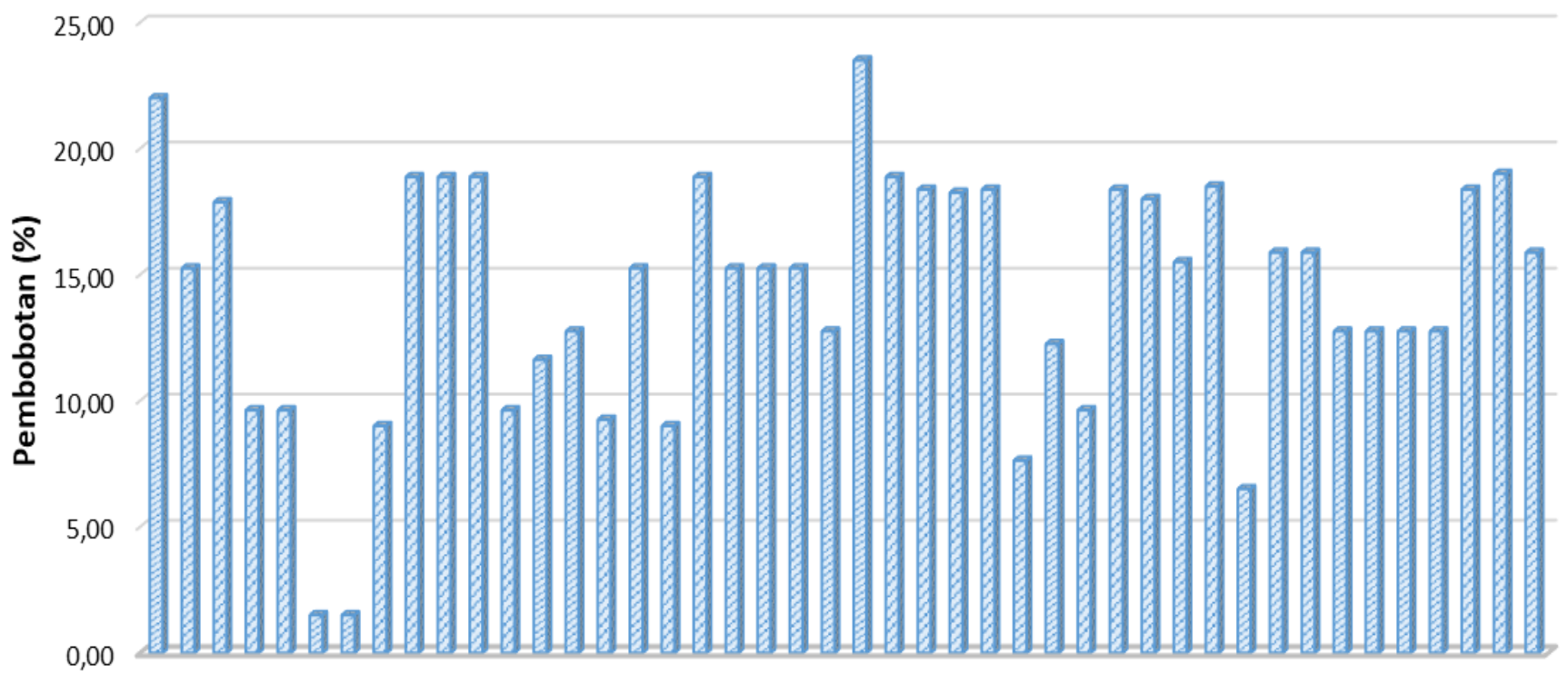

1234567891011121314151617181920212223242526272829303132333435363738394041424344 Geosite

Gambar 3. Hasil penilaian berdasarkan keanekaragaman geologi (geodiversity) di setiap lokasi. 


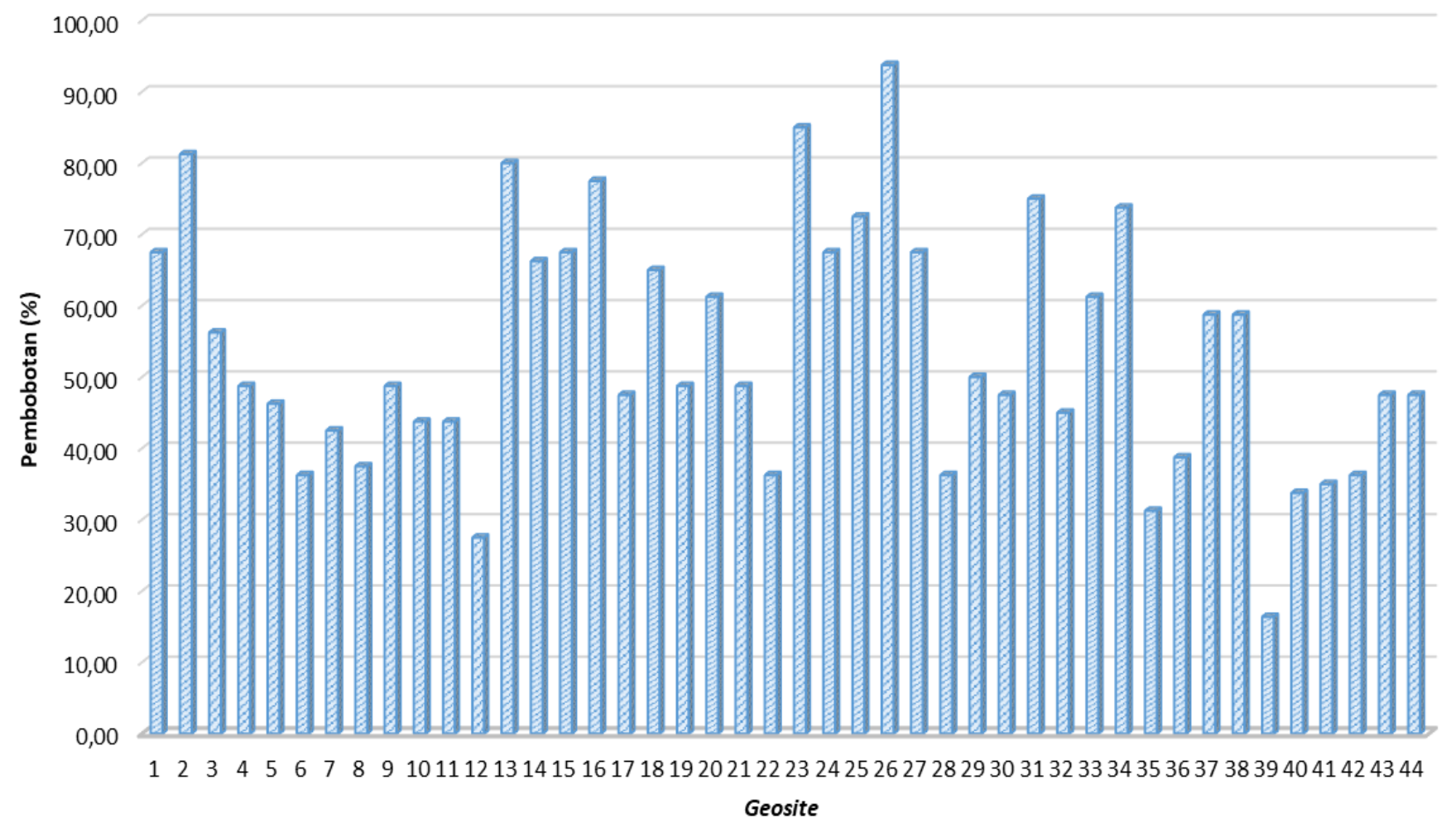

Gambar 4. Hasil penilaian lokasi-lokasi geodiversity yang memiliki nilai keilmuan.

7. Bukit Kunyit (1): Bukit Kunyit berada di kota Bandar Lampung dan menunjukkan struktur lipatan dan kekar kolom. Lokasi ini merupakan bukit terisolasi yang berada di pesisir selatan Kota Bandar Lampung. Lokasi ini memiliki bentang alam yang menarik, yaitu kehadiran kekar kolom yang terbentuk dari material tuf dalam Formasi Lampung (QTI), berumur Kuarter (Gambar 1 dan 2) [7]. Selain itu variasi batuan, mineral, dan juga struktur geologi di daerah ini memberikan nilai geodiversity 22\% (Gambar 3) dan aspek ilmiah 67,5\% (Gambar 4). Daerah ini dapat dicapai dengan mudah dengan menggunakan kendaran pribadi maupun umum, sayangnya saat ini lokasi Bukit Kunyit menjadi area tambang rakyat (sebagai Tambang Bahan Galian C). Sekali pun Bukit Kunyit memiliki lokasi kunci yang sedikit tapi material piroklastik dan juga struktur primer yang terbentuk di daerah ini menunjukkan hubungan dengan aktivitas magmatisme tua berumur Kuarter [6]. Pesebaran titik pengamatan dan juga akses menuju daerah yang mudah memberi nilai tambah pada aspek ilmiah.
8. Pantai Marina (25): Pantai indah ini berada di Kecamatan Kalianda, Lampung selatan. Pantai berbatu ini tersusun atas batuan sedimen volkaniklastik dan piroklastik berumur Miosen Akhir atau sekitar 11-5 juta tahun lalu (Gambar 1 dan 2) [6]. Di beberapa titik ditemukan fitur struktur geologi seperti lipatan dan patahan. Terdapat beberapa gua laut di sekitar pantai ini yang terbentuk dari hasil abrasi. Keanekaragaman geologi ini memiliki nilai cukup tinggi, yaitu 18,38\% (Gambar 3). Objek geodiversity di daerah ini dapat dilihat tersebar luas di sepanjang pesisir pantai dengan kondisi situs yang cukup baik untuk diamati. Kehadiran struktur dan lipatan di daerah ini menunjukkan adanya proses tektonik yang cukup intensif terjadi. Namun, pemahaman keilmuan dan penelitian pada lokasi ini sangat sedikit dan perlu adanya penelitiaan lebih lanjut mengenai kerangka tektonik yang berkembang di sepanjang pesisir Pantai Marina. Tidak sulit mencapai pantai indah karena berada dekat dengan 
Kota Kalianda. Hasil penilaian aspek ilmiah lokasi ini adalah 72,5\% (Gambar 4).

9. Pantai Minang Rua (24): Pantai ini terletak di muara sungai yang dibatasi oleh perbukitan vulkanik purba Gunung Rajabasa, Lampung Selatan, yang tersusun atas lava dan piroklastik yang terbentuk sekitar 5-2 juta tahun lalu (Gambar 1 dan 2) [6]. Ke arah hulu sungai terdapat air terjun yang menyingkapkan jelas formasi-formasi batuan ini. Berdasarkan litologi dan juga struktur yang berkembang di lokasi tersebut, Pantai Minang Rua memiliki nilai geodiversity 18,88\% (Gambar 3). Keanekaragaman geologi ini juga dapat ditemukan disepanjang pantai dan juga sepanjang jalan menuju pantai. Untuk menuju Pantai Minang Rua, dapat menggunakan kendaraan pribadi melalui jalan yang cukup curam. Namun keindahan bentang alam pantai ini layak untuk dinikmati. Sekali pun memiliki banyak singkapan batuan vulkaniklastik dan juga lava, masih sedikit penelitian yang dilakukan di daerah ini. Selain memiliki nilai geodiversity, pantai ini juga merupakan tempat bertelur bagi penyu hijau dan penyu belimbing [27]. Pada tahun 2018 pantai ini mengalami dampak tsunami hasil dari erupsi Gunung Anak Krakatau [28]. Pantai Minang Rua memiliki nilai aspek ilmiah 67,5\% (Gambar 4).

10.Sumber Air Panas Sesar Lampung-Panjang (15): Lokasi ini merupakan manifestasi aktivitas sesar bawah permukaan yang berinteraksi dengan sistem air tanah dan membentuk luapan sumur airpanas [29]. Berawal dari aktivitas pemboran dangkal untuk irigasi sawah, yang justru meluapkan limpahan air panas di permukaan. Ketersediaan airpanas yang terus-menerus menjadikan area ini sebagai destinasi pemandian airpanas. Lokasi ini berada pada kelurusan sesar Lampung-Panjang, namun variasi litologi dan mineral di daerah ini tidak cukup variatif. Hasil penilaian geodiversity di daerah ini adalah 9,25\% (Gambar 3). Nilai ini merupakan nilai terkecil dibandingkan 13 lokasi geodiversity lainnya. Lokasi ini berada tepat di pinggir jalan Trans-Sumatera, Kota Bandar Lampung dan dikelilingi hamparan sawah. Jika kondisi cuaca cerah, maka dapat langsung mengamati kepudan Gunung Betung. Sekalipun memiliki nilai geodiversity yang rendah, namun aspek ilmiah lain pada daerah ini cukup tinggi. Kehadiran mata air panas pada kelurusan Sesar LampungPanjang menunjukkan adanya aktivitas tektonik yang berkembang di daerah ini [29]. Lokasi situs ini pun cukup terjaga. Oleh karena itu hasil penilaian aspek ilmiah lokasi ini adalah 67,5\% (Gambar 4).

11. Komplek Purbakala Pugung Raharjo (13): Lokasi geodiversity ini berada di Kota Bandar Lampung. Komplek Purbakala Pugung Raharjo merupakan punden berundak yang muncul ketika era Megalitikum, memiliki struktur yang selaras dengan arah mata angin dan merupakan Benda Cagar Budaya Indonesia di Provinsi Lampung [30]. Komplek Purbakala Pugung Raharjo berada pada litologi basal yang dikategorikan sebagai Basal Sukadana (Qbs), berumur Holosen (Gambar1 dan 2) [6]. Lokasi ini memiliki bentang alam yang indah dan juga variasi batuan yang menarik, sehingga nilai geodiversity daerah ini adalah 11,63\% (Gambar 3). Sudah banyak penelitian mengenai aspek budaya yang dilakukan di lokasi ini, namun pemahaman aspek geologi masih perlu untuk dilakukan. Litologi basal yang terjaga di daerah ini menunjukkan aktivitas magmatisme pada saat Pulau Sumatera dan Pulau Jawa mulai terpisah [31]. Berdasarkan hal tersebut, maka penilaian aspek ilmiah di daerah ini adalah 80\% (Gambar 4).

12. Komplek Goa Pandan Sumur Kubah (27): Goa Pandan, menurut catatan beberapa sumber, merupakan goa yang terpanjang dan terlebar yang ditemukan di Lampung Timur. Gua ini memiliki lebar kira-kira 4 meter, tinggi rata-rata 2,5 meter, dan panjang gua yang diketahui mencapai 200 meter. Di beberapa bagian, tinggi gua hanya mencapai 1 meter dikarenakan ada reruntuhan batu dari atas langitlangit goa. Area Gua Pandan ini termasuk dalam satuan litologi Lava Sukadana (Qbs) [6], namun jenis batuan yang menyusun gua belum diketahui pasti (Gambar 1 dan 2). Ada beberapa hal unik dan menarik di dalam gua ini, terdapat batu yang menyerupai kursi, ada pula ruangan di atas dinding gua yang luas menyerupai balkon. Juga ada lubang pada langit-langit gua yang apabila terkena sinar matahari akan menunjukan kolom-kolom cahaya. Hal-hal unik ini masih perlu diteliti lebih lanjut untuk memberikan gambaran jelas asal dari batuan tersebut. Berdasarkan aspek geologi tersebut, lokasi ini memiliki nilai geodiversity 18,38\% (Gambar 3) dan aspek ilmiah 67,50\% (Gambar 4).

13.Gunung Rajabasa (14): Gunung Rajabasa (Qhv) merupakan gunungapi Kuarter (Tipe C) di ujung selatan Pulau Sumatera (Gambar 1 dan 2) [32], beberapa hasil laporan mengatakan bahwa 
ditemukan fosil kayu pada endapan piroklastik di kaki gunung tersebut. Gunung Rajabasa memiliki potensi panas bumi (telah dieksploitasi) sebagai pembangkit listrik tenaga geotermal dan pemandian airpanas [33]. Lokasi geodiversity ini memiliki litologi dan struktur vulkanik yang cukup beragam. Selain itu pesebaran dan pembentukan Gunung Rajabasa tidak bisa lepas dari aktivitas tektonik yang berkembang di daerah ini. Oleh sebab itu, Gunung Rajabasa memiliki nilai geodiversity $12,75 \%$ (Gambar 3) dan aspek ilmiah 66,25\% (Gambar 4). Nama Rajabasa sendiri merupakan nama marga penduduk asli yang berasal dari kaki gunung tersebut, penyebutan ini dikarenakan kemampuannya menggunakan berbagai bahasa (terutama yang berkaitan dengan bahasa sehari-hari perdagangan di kawasan Selat Sunda).

14.Gunung Anak Krakatau (26): Komplek Gunung Anak Krakatau terletak di Selat Sunda dan berada diantara Pulau Sumatera dan Pulau Jawa. Daerah ini disusun oleh produk gunung api berumur Kuarter (Gambar 2) [6]. Krakatau (atau Rakata) adalah kepulauan vulkanik yang masih aktif dan berada di Selat Sunda. Nama ini juga disematkan pada satu puncak gunung berapi di sana (Gunung Krakatau) yang sirna karena letusan kataklismik pada tanggal 26-27 Agustus 1883 [13]. Guncangan erupsi ini terasa hingga Australia dan membawa tsunami besar di sepanjang pantai Selat Jawa. Material yang dihasilkan letusan dasyat ini tersebar keseluruh dunia dan menyebabkan musim dingin menahun di Eropa. Kawasan yang sekarang merupakan cagar alam ini memiliki empat pulau kecil: Pulau Rakata, Pulau Anak Krakatau, Pulau Sertung, dan Pulau Panjang (Rakata Kecil).

Pada tahun 1927, pulau keempat, Anak Krakatau, atau "Anak Krakatau", muncul dari kaldera yang terbentuk pada tahun 1883 . Telah terjadi aktivitas letusan baru sejak akhir abad ke-20, dengan keruntuhan besar yang menyebabkan tsunami mematikan pada bulan Desember 2018 [10]. Berdasarkan proses pembentukannya, aktivitas magmatisme dan tipe letusan, serta dampak yang ditimbulkan oleh gunung ini, lokasi geodiversity Gunung Anak Krakatau memiliki nilai geodiversity 18,25\% (Gambar 3) dan aspek ilmiah 93,75\% (Gambar 4).

Data keempat belas lokasi geodiversity di atas tidak dapat dilepaskan dari tatanan tektonik dan evolusi Pulau Sumatera yang berlangsung sejak Permian hingga saat ini. Subduksi Lempeng Eurasia dan Paparan Sunda pada Kala Permian menghasilkan amalgamasi antara Sibumasu, Mergui, dan Catasia yang membentuk Pulau Sumatera [34]. Hasil subduksi ini berupa variasi litologi batuan metamorf yang dikenal dengan Batuan Komplek Gunung Kasih. Proses pembentukan batuan metamorf disertai juga dengan aktivitas magmatisme dan menghasilkan batuan migmatit [25]. Titik lokasi geodiversity yang menyimpan rekaman evolusi tektonik ini berada di Jeram Migmatit Natar dan Bukit Malihan Pra-Tersier Panjang.

Aktivitas magmatisme terus berlanjut sepanjang jalur subduksi hingga Kapur Akhir dan menghasilkan Diorit Sekampung dan Granodiorit Sulan [6] yang dapat diamati di Bukit Granit Indah.

Zaman Eosen hingga Paleosen, afinitas magma di bagian barat Pulau Sumatera bersifat lebih kalk-alkalin dan membentuk jajaran gunung api yang dikenal dengan Bukit Barisan. Di daerah penelitian, afinitas magma kalkalkalin merupakan bagian dari Formasi Tarahan dan Formasi Hulusimpang, yang dikenal dengan Satuan Old Andesit [6]. Bukti dari aktivitas magmatisme ini dapat diamati pada lokasi Kaldera Gebang, Pantai Sari Ringgung, Pantai Batu Lapis, dan Pantai Marina.

Pada Zaman Kuarter, sebagian besar aktivitas magmatisme Provinsi Lampung berada di bagian selatan Lampung [31]. Hal ini ditandai dengan kehadiran bentukbentuk tubuh gunungapi tua dan gunungapi muda yang dapat memberikan pengaruh secara lokal maupun global. Produk vulkanik tertua di daerah penelitian tersusun dari lapisan tuf yang merupakan bagian dari Formasi Lampung. Lapisan tuf ini tersebar cukup luas di Lampung bagian selatan dan memiliki ketebalan lebih dari $100 \mathrm{~m}$. Pada Bukit Kunyit singkapan Formasi Lampung hadir dalam bentuk kekar kolom. Produk breksi vulkanik dari Formasi Lampung juga dapat dijumpai di Pantai Minang Rua.

Di atas Formasi Lampung terdapat Basalt Sukadana yang berumur Holosen. Menurut Zulkarnain [31], Basal Sukadana memiliki kesamaan karakteristik dengan basal yang berasal dari busur kepulauan (island arc). Di daerah penelitian, singkapan Basal Sukadana dapat diamati di lokasi geodiversity Komplek Purbakala Pugung Raharjo dan Komplek Goa Pandan Sumur Kubah.

Aktivitas tektonik yang berkembang di Provinsi Lampung tidak lepas dari proses penunjaman di bagian barat Pulau Sumatera dan menghasilkan Sesar Sumatera. 
Kelurusan-kelurusan yang berkembang di Provinsi Lampung memiliki arah yang sama dengan Sesar Sumatera. Pengaruh dari Sesar Sumatera dapat dilihat dari bukti sebaran produk vulkanik Gunung Betung, kehadiran struktur patahan dan lipatan di Pantai Marina, dan juga kehadiran sumber mata air panas Sesar Lampung-Panjang.

Selain dari Formasi Lampung dan Basal Sukadana yang menandakan adanya aktivitas magmatisme purba di daerah penelitian, terdapat juga gunung api strato, berumur Holosen, bertipe $\mathrm{C}$ di bagian pesisir selatan Provinsi Lampung, Gunung Rajabasa. Sekalipun terjadi peninggkatan aktivitas magmatisme pada tahun 1863 dan 1892, namun tidak diketahui pasti kapan terakhir kali gunungapi ini meletus. Namun, kehadiran mata air panas, berupa fumarol, di daerah ini menandakan adanya sumber panas yang berasosiasi dengan magmatisme Gunung Rajabasa.

Aktivitas vulkanik Resen di daerah penelitian yang memberi dampak pada kehidupan manusia moderen, secara lokal atau pun global terdapat di Gunung Anak Krakatau. Sekali pun saat ini ketinggian Gunung Anak Krakatau tidak sama seperti Gunung Krakatau, namun kedahsyatan letusannya mampu dirasakan secara langsung oleh manusia. Salah satunya adalah tsunami yang terjadi pada 2018 yang menyapu sebagian pesisir selatan Lampung dan juga Banten. Bukti ketinggian gelombang tsunami tahun 2018 dapat diamati pada lokasi geodiversity Pantai Minang Rua. Selain itu, aktivitas Gunung Rakata pada tahun 1883 dapat dirasakan hingga Australia. Efek global yang disebabkan letusan Gunung Rakata 1883 telah menginspirasi Edvard Munch asal Norwegia yang menghasilkan karya "The Scream" pada tahun 1893.

\section{Kesimpulan dan Saran}

Provinsi Lampung memiliki potensi geodiversity yang beragam dan berkaitan erat dengan evolusi tektonik Pulau Sumatera, evolusi magmatisme purba, dan aktivitas vulkanisme berumur Resen yang dapat memberi dampak lokal maupun global pada kehidupan manusia moderen. Potensi geodiversity yang dapat menunjukkan hubungan evolusi tektonik dan vulkanisme di daerah penelitian dapat ditemukan pada 14 lokasi geodiversity, yaitu Jeram Migmatit Natar, Bukit Malihan Pra-Tersier Panjang, Bukit Granit Indah, Pantai Sari Ringgung, Kaldera Purba Gebang, Pantai Batu Lapis, Bukit Kunyit, Pantai Marina, Pantai Minang Rua, Sumber
Air Panas Sesar Lampung-Panjang, Komplek Purbakala Pugung Raharjo, Komplek Goa Pandan Sumur Kubah, Gunung Rajabasa, dan Gunung Anak Krakatau.

Penelitian lapangan diperlukan dalam proses perkembangan kawasan wisata Krakatau-Way Kambas. Sehingga dapat menambah nilai ilmiah, khususnya geologi, dan pemahaman menyeluruh terkait evolusi tektonik Provinsi Lampung, evolusi magmatisme purba, dan aktivitas vulkanisme berumur Holosen.

\section{Konflik Kepentingan}

Tidak ada konflik kepentingan dalam penelitian ini.

\section{Ucapan Terima Kasih}

Ucapan terima kasih ditujukan kepada Pusat Riset dan Inovasi Wisata Geopark Global dan Wisata Langit.

\section{Daftar Pustaka}

[1] M. Gray, "Geodiversity: Valuing and Conserving Abiotic Nature," New York: John Wiley \& Sons, 2004.

[2] J. Brilha, "Inventory and Quantitative Assessment of Geosites and Geodiversity Sites: a Review," Geoheritage, vol. 8, no. 2, hal. 119-134, 2016.

[3] J. Hjort, J. E. Gordon, M. Gray, dan M. L. Hunter, "Why geodiversity matters in valuing nature's stage," Conserv. Biol. J. Soc. Conserv. Biol., vol. 29, no. 3, hal. 630-639, 2015.

[4] M. Gray, "Geodiversity and Geoconservation: What, Why, and How?," The George Wright Forum, vol. 22, no. 3, hal. 4-12, 2005.

[5] Peraturan Presiden, "Pengembangan Taman Bumi (Gepark)," 2019.

[6] S. Andi Mangga, Amiruddin, T. Suwarti, S. Gafoer, dan Sidarto, "Geologi Lembar Tanjungkarang, Sumatera." Pusat Penelitian dan Pengembangan Geologi, 1994.

[7] S. A. Mangga, Amiruddin, T. Suwarti, S. Gafoer, dan Sidarto, "Peta geologi lembar Tanjung Karang, Sumatera," 1993.

[8] T. C. Amin, Sidarto, S. Santosa, dan W. Gunawan, "Peta geologi lembar Kotaagung, Sumatera," 1993.

[9] Permana, Haryadi, Muasri, S. Aribowo, dan M.M. mukti, "Petrologi Batuan Dasar Kompleks Gunung Kasih, Tanjungkarang, Lampung Selatan," Prosiding Geoteknologi Lipi, 2017.

[10] S. Winchester, "Krakatoa: The Day the World Exploded: August 27, 1883," United Kingdom: Penguin, 2004. 
[11] J. H. Latter, "Tsunamis of volcanic origin: Summary of causes, with particular reference to Krakatoa, 1883," Bull. Volcanol., vol. 44, hal. 467-490, 1981.

[12] N. Schaller, T. Griesser, A. Fischer, A. Stickler, dan S. Brönnimann, "Climate effects of the 1883 Krakatoa eruption: Historical and present perspectives," Vierteljahrsschr. Naturforschenden Ges. Zuerich, vol. 154, hal. 31-40, 2009.

[13] Pusat Vulkanologi dan Mitigasi Bencana Geologi, "Gunung Krakatau," https://vsi.esdm.go.id/index.php/gunungapi/data-dasargunungapi/509-g-krakatau?start=1 (diakases 25 Oktober, 2020).

[14] P. Gleckler, K. Achutarao, J. Gregory, B. Santer, dan T. Wigley, "Krakatoa lives: The effect of volcanic eruptions on ocean heat content and thermal expansion," Geophys Res Lett, vol. 33, 2006.

[15] W. Pusparini T. Batubara, F. Surahmat, A. T. Sugiharti, M. Muslich, F. Amama, W. Marthy, dan N. Andayani, "A pathway to recovery: The Critically Endangered Sumatran tiger Panthera tigris sumatrae in an 'in danger' UNESCO World Heritage Site," ORYX, vol. 52, no. 1, hal. 25-34, 2018.

[16] R. Sawitri, A. S. Mukhtar, dan N. M. Heriyanto, "Biodiversity and management of estuarine ecosystem in Way Kambas National Park, Lampung (Indonesia)," Bul. Penelit. Hutan Indones., 1998.

[17] W. B. Hamilton, "Tectonic of The Indonesian Region," 1979.

[18] R. McCaffrey, "The Tectonic Framework of the Sumatran Subduction Zone," Annu. Rev. Earth Planet. Sci., vol. 37, no. 1, hal. 345-366, 2009.

[19] N. R. Cameron, M. C. G. Clarke, D. T. Aldiss, J. A. Aspden, dan A. Djunuddin, "The Geological Evolution of Northern Sumatera," The $9^{\text {th }}$ Annual Conv. Pros. of American Association of Petroleum Geosc, hal. 149-187, 1980.

[20] J. A. Katili, "Geology of Southeast Asia with particular reference to the South China Sea," Energy, vol. 6, no. 11, hal. 1075-1091, 1981.

[21] S. Gafoer, "Tinjauan Kembali Tatanan Stratigrafi Pra-Tersier Sumatera Bagian Selatan," Pros. Persidang. Sains Bumi Dan Masy. Malays. Nas. Univ.

[22] S. Suparka and S. Asikin, "Pemikirkan Perkembangan Tektonik PraTersier di Sumatera Bagian Tengah," Ris. Geol. Dan Pertamb., vol. 1, hal. 1-13.

[23] Peraturan Menteri Energi dan Sumber Daya Mineral Nomor 1, "Pedoman Penetapan Warisan Geologi (Geoheritage)," Diakses pada 31 September, $2021 . \quad$ Available: https://jdih.esdm.go.id/storage/document/Permen\%20ESDM\%20No mor\%201\%20Tahun\%202020.pdf.
[24] Kementerian Energi dan Sumber Daya Mineral, "Petunjuk Teknik Asesmen Sumber Daya Warisan Geologi," Badan Geologi, 2017.

[25] M. G. Sagara, "Morfologi, Petrografi, dan Kimia Mineral Migmatit Jundeng, Lampung," Bandung: Institut Teknologi Bandung, Skripsi tidak dipublikasikan, 2016.

[26] K. Fowler-Billings, "The Geology of the Monadnock Quadrangle New Hampshire," N.H. Planning and Development Commission, 1949.

[27] P. T. Yatmaja, "Efektivitas Pemberdayaan Masyarakat oleh Kelompok Sadar Wisata (POKDARWIS) dalam Mengembangkan Pariwisata Berkelanjutan," Adm. J. IIm. Adm. Publik Dan Pembang., vol. 10, no. 1, hal. 27-36, 2019.

[28] R. E. N. Siregar, A. Zakaria, dan A. Armijon, “Kajian Daerah Rendaman tsunami di Pesisir Teluk Lampung Akibat Perubahan Topografi Gunung Anak Krakatau di Tahun 2018," J. Geofis. Eksplor., vol. 6, no. 1, hal. 31-41, 2020.

[29] Suharno, R. B. Aritonang, A. Zainudin, dan Rustadi, "Sistem Panas Bumi Cisarua Natar Lampung Selatan," Pro. The $12^{\text {th }}$ Ann. Indonesia Geothermal Ass. Meet. And Conf., 2012.

[30] W. J. Riskawati, “Persepsi Wisatawan Terhadap Obyek Wisata Taman Purbakala Pugung Raharjo di Desa Pugung Raharjo Kecamatan Sekampung Udik Kabupaten Lampung Timur Tahun 2015," Lampung: Universitas Lampung, Skripsi tidak dipublikasikan, 2015.

[31] I. Zulkarnain, "Geochemical Evidence of Island-Arc Origin for Sumatra Island; A New Perspective based on Volcanic Rocks in Lampung Province, Indonesia," Indones. J. Geosci., vol. 6, no. 4, 2011.

[32] K. Kusumadinata, "Data Dasar Gunung Api Indonesia." Dit. Vulkanologi, Bandung, 1979.

[33] Pusat Sumber Daya Mineral, Batubara, dan Panas Bumi, "Potensi panas bumi Indonesia, Edisi pertama," Jakarta: Direktorat Panas Bumi, Direktorat Jenderal Energi Baru, Terbarukan, Konservasi Energi, Kementerian Energi dan Sumber Daya Mineral, 2017.

[34] A. J. Barber, M. J. Crow, dan J. Milsom, "Sumatra: geology, resources and tectonic evolution, " London: The Geological Society, 2005. 